\title{
Traditional Knowledge of the Ecology of Beluga Whales (Delphinapterus leucas) in the Northern Bering Sea, Chukotka, Russia
}

\author{
NIKOLAI I. MYMRIN, ${ }^{1}$ THE COMMUNITIES OF NOVOE CHAPLINO, SIRENIKI, UELEN, AND YANRAKINNOT, \\ and HENRY P. HUNTINGTON ${ }^{2}$
}

(Received 20 February 1998; accepted in revised form 5 August 1998)

\begin{abstract}
The first systematic effort to document traditional ecological knowledge (TEK) of beluga whales (Delphinapterus leucas) in Russia was conducted in the villages of Sireniki, Novoe Chaplino, Yanrakinnot, and Uelen, in the Chukotka Autonomous Okrug. The findings describe migratory and local movements, feeding, calving, ecological interactions, and human influences on distribution and behavior. The results add considerable detail to published accounts of belugas in Russian waters of the Bering and Chukchi Seas. Among these are descriptions of avoidance and habituation responses to anthropogenic noise, which appear to depend in part on association with hunting activities. The authors observe that most of the TEK documented in this study came from older hunters, and that the collective pool of traditional knowledge in the region is disappearing.
\end{abstract}

Key words: beluga whales, white whales, Delphinapterus leucas, Bering Sea, Chukchi Sea, Chukotka, ecology, traditional ecological knowledge, TEK

RÉSUMÉ. La première tentative systématique en vue de documenter le savoir écologique traditionnel (SET) sur les bélougas (Delphinapterus leucas) en Russie a été menée dans les villages de Sireniki, de Novoe Chaplino, de Yanrakinnot et de Uelen, dans l'arrondissement autonome des Tchouktches. Les résultats décrivent les déplacements migratoires et locaux, la nutrition, la mise bas, les interactions écologiques et les influences humaines sur la distribution et le comportement. Les résultats apportent de nombreux détails aux relevés de bélougas dans les eaux russes de la mer de Béring et de la mer des Tchouktches. Ces nouveaux détails incluent la description des réactions d'évitement et d'accoutumance au bruit anthropique, qui semble dépendre en partie de l'association avec les activités cynégétiques. Les auteurs observent que la plupart du SET documenté dans cette étude vient de vieux chasseurs et que le bassin collectif du savoir traditionnel dans la région est en train de disparaître.

Mots clés: bélougas, baleines blanches, Delphinapterus leucas, mer de Béring, mer des Tchouktches, arrondissement autonome des Tchouktches, écologie, savoir écologique traditionnel, SET

Traduit pour la revue Arctic par Nésida Loyer.

\section{INTRODUCTION}

Beluga whales (Delphinapterus leucas) are abundant in the coastal waters of Chukotka, Russia, distributed from the Gulf of Anadyr to the Chukchi Sea (Tomilin, 1957; Kleinenberg et al., 1964; Sobolevsky and Mathisen, 1996). Chukotka shares its stock with Alaska and perhaps with Canada. Belugas are hunted occasionally in Chukotka, but are not a staple of the subsistence diet. Nonetheless, Native hunters of the region are familiar with the ecology and biology of beluga whales, both from hunting belugas and from opportunistic observations made while pursuing walrus (Odobenus rosmarus divergens) and seals (Phoca spp. and Erignathus barbatus).

This research, which was carried out in conjunction with research in Alaska (Huntington et al., 1999), documented traditional ecological knowledge (TEK) about beluga whales held by elders and hunters in four villages of Chukotka: Sireniki, Novoe Chaplino, Yanrakinnot, and Uelen (Fig. 1). (For fuller discussion of the strengths and limitations of TEK, see Huntington et al., 1999.) These communities were selected on the basis of the intensity of their use of belugas, although belugas are not hunted in substantial numbers in Chukotka: perhaps a few dozen a year are taken, at most. This study did not attempt to document harvest practices or levels.

Chukotka, an autonomous okrug (region) that was formerly part of the Magadan Oblast, is the extreme northeastern tip of Asia. It is home to several indigenous groups, two of whom, the Chukchi and the Yupik (or Eskimos), inhabit the coast of the Chukotka Peninsula. The Yupik are related to the Yupik of St. Lawrence Island, Alaska, while the Chukchi are linguistically and culturally distinct (Huntington, 1998a).

Marine mammal hunting has for centuries been a dominant factor in the coastal economy of Chukotka (Krupnik,

\footnotetext{
${ }^{1}$ Dezhneva 53-15, Provideniya, Chukotka 686910, Russia

${ }^{2}$ Corresponding author: Inuit Circumpolar Conference, 401 E. Northern Lights Blvd., Suite 203, Anchorage, Alaska 99503; present address: Huntington Consulting, P.O. Box 773564, Eagle River, Alaska 99577, U.S.A.; hph@alaska.net

(C) The Arctic Institute of North America
} 


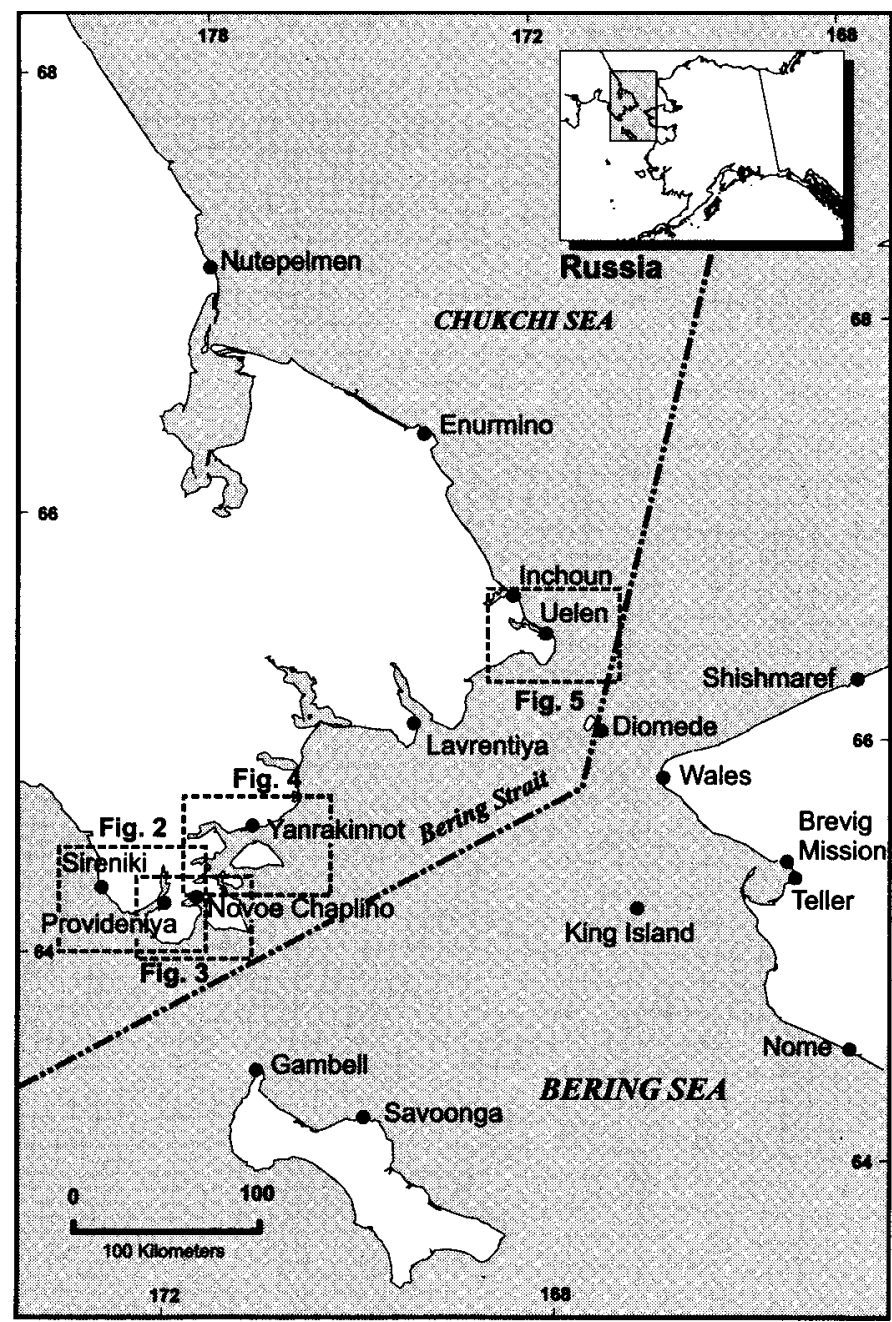

FIG. 1. Locations of study, eastern Chukotka.

1994), which shares species and stocks of marine mammals with Alaska. Bowhead (Balaena mysticetus) and gray whales (Eschrichtius robustus), beluga whales, walrus, polar bear (Ursus maritimus), and seals, as well as migratory ducks and geese (various spp.), are hunted on both sides of the Bering Strait. Under the Soviet system of collectivization, farms to raise arctic foxes (Alopex lagopus) were established in most villages, and much marine mammal meat and blubber was harvested for the foxes (Sander, 1992).

\section{METHODS}

The method used in this study is the semi-directive interview, as described in greater detail in Huntington (1998b) and Huntington et al. (1999). The interviews were conducted by Mymrin. He traveled to Sireniki, Novoe Chaplino, and Yanrakinnot in the spring of 1995 to plan the fieldwork, identify participants, and conduct interviews, primarily with individual participants. The review sessions took place in the winter and spring of 1996, and participants were also able to send comments on the draft to Mymrin.
While logistics made it impossible for Mymrin himself to conduct fieldwork in Uelen, Vasili I. Iorelo, a Chukchi from Uelen and past collaborator with Mymrin, was willing to undertake the research. This arrangement allowed us to obtain some information about belugas from another, and more remote, area of Chukotka, and it is perhaps a replicable way of obtaining information from very remote areas. In all cases, in accordance with established ethical principles (Interagency Arctic Research Policy Committee, 1992), participants signed release forms indicating their willingness to take part in the research.

The participants in the project were selected with the help of the community council and elders in each village. Mymrin began the research with group or individual interviews, recording them on tape. Later, he prepared printed reports and returned these to the participants for corrections and additions. Following this review, he again conducted individual interviews, asking questions to clarify and expand what was in the report. During this stage, some of the hunters wrote to him and submitted additional notes. This information has been added to the relevant sections of the report. Huntington and Mymrin (1996) include the text of these contributions along with descriptions of the participants and their experiences.

\section{RESULTS}

To avoid duplicating information in the presentation of results, we have combined the data from the four communities in which this study was conducted, identifying the particular site only when pertinent or when discrepancies were noted.

\section{The Communities}

Sireniki is located on the Bering Sea at the mouth of the Sirenek-Keyvuk River (Fig. 2). It is an ancient Yupik settlement, and the present location has been occupied for several centuries. Sireniki hunters are familiar with the coast from Cape Chukotskiy to Kurupka, and some of the participants had experience in the Kresta Bay area to the west, and in the Seniavin Strait area to the east (Fig. 4).

Novoe Chaplino is located on the north shore of Tkachen Bay (Fig. 3). It was built in 1958, relocating the village from Cape Chaplin and consolidating other small settlements. In 1993, the village population was 497. Novoe Chaplino hunters are familiar with the area from Arakamchechen Island (Fig. 4) in the north to Cape Chukotskiy in the south. This area reflects, in part, the range of places in which the participants lived before the relocation and consolidation of the village in 1958.

Yanrakinnot is located on the northern mainland shore of Seniavin Strait, at the mouth of the Marich River (Fig. 4). Its population in 1989 was 473 . The hunters from Yanrakinnot are familiar with the local area, from Chechekuyim Strait (Fig. 3) in the south to Cape Nygligan 


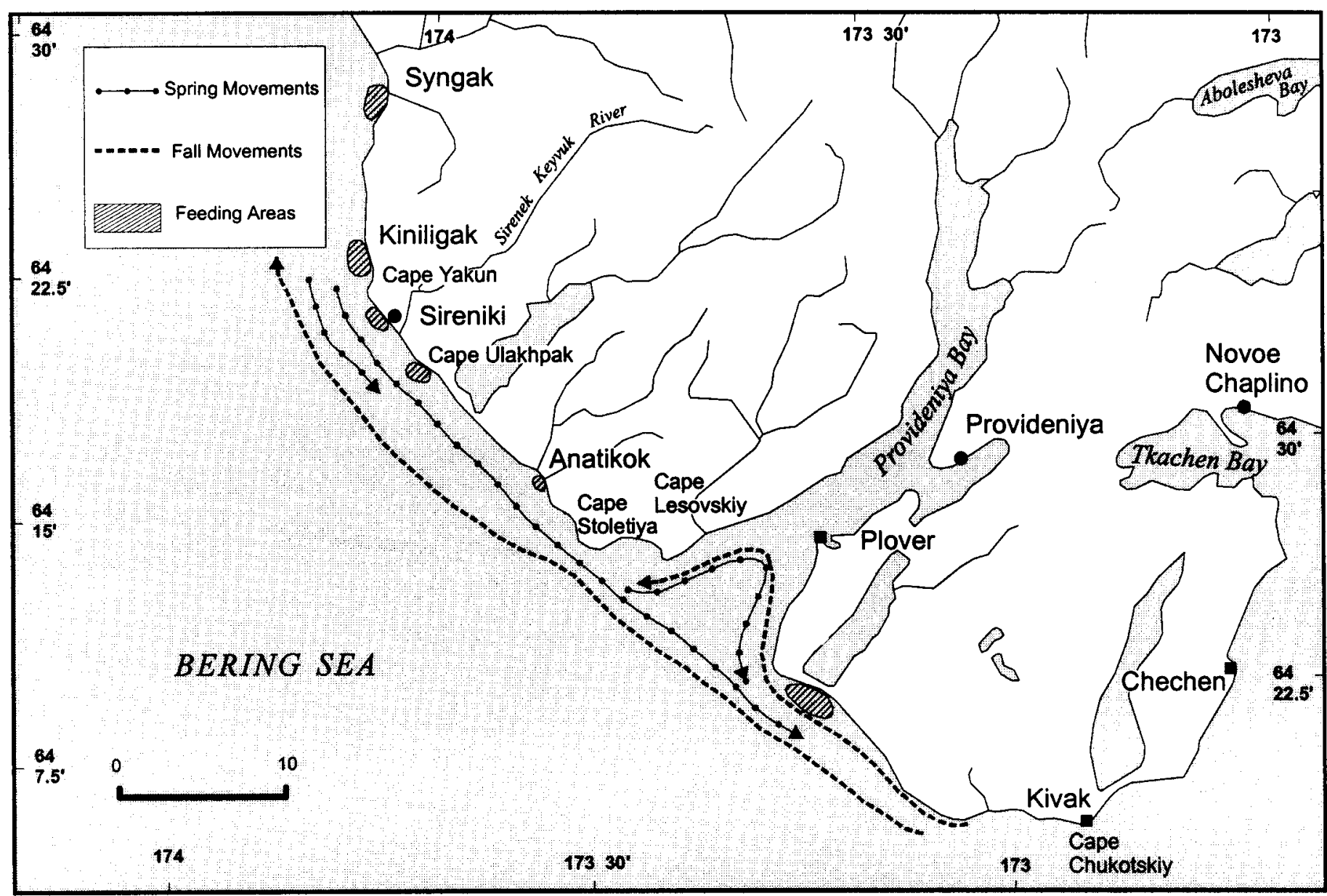

FIG. 2. Spring and fall movements and feeding areas of belugas near Sireniki.

and farther to the north. They hunt in Seniavin Strait and Penkignei Bay, and around Arakamchechen and Yttigran Islands. The participants are also familiar with other areas; during their travels they have seen belugas in the Anadyr River (approximately $450 \mathrm{~km}$ west of Provideniya) and near the mouth of Provideniya Bay.

Uelen is the largest village on the northern coast of Chukotka (Fig. 5). In 1989, its population was 1034. The area around Uelen includes the western Bering Strait and the coast of the Chukotka Peninsula extending along the Bering and Chukchi Seas.

\section{Distribution and Migration}

In spring, the belugas migrate east and north along the coast of Chukotka. The migration may begin as early as March and extend until June. The belugas typically migrate close to shore, but their movement is influenced by the extent of the sea ice. If there is much pack ice, the migration is close to shore; if there is open water, the animals may be as far as $8-10 \mathrm{~km}$ offshore. Only when extensive ice fields are encountered do the belugas turn back, delaying the spring migration.

Most belugas observed during the spring migration are adults. Few young are seen, though perhaps they follow a different route. The adults usually migrate in groups of five to ten whales. Sometimes, larger groups of up to 100 belugas can be seen, and these may include younger belugas. Single belugas are usually white (i.e., adult) and male. At Uelen, males are the first to arrive, followed by females and young.

The belugas typically do not stay long in the Sireniki area (Fig. 2), although if arctic cod (Boreogadus saida) are abundant, large numbers of belugas may stay between Cape Yakun and Cape Ulakhpak to feed. In the Novoe Chaplino area (Fig. 3), most belugas pass in May. They are usually observed from the ice edge in Tkachen Bay, since the bay itself is usually ice covered at this time of year. In spring, belugas usually feed at the ice edge near Alayon, northeast of Yanrakinnot (Fig. 4). In May and June, they feed at the edge, swimming in both directions, though by June they are usually moving to the northeast. In some years, belugas are not seen, as was the case in 1994. At Uelen (Fig. 5), belugas migrate along Cape Peek and Cape Vostochnyi.

Few belugas are seen in summer near any of the communities. They do not appear every year, and when they do arrive, they are usually males traveling alone. In fall, belugas migrate south and west beginning in September. The main fall migration takes place in October and 


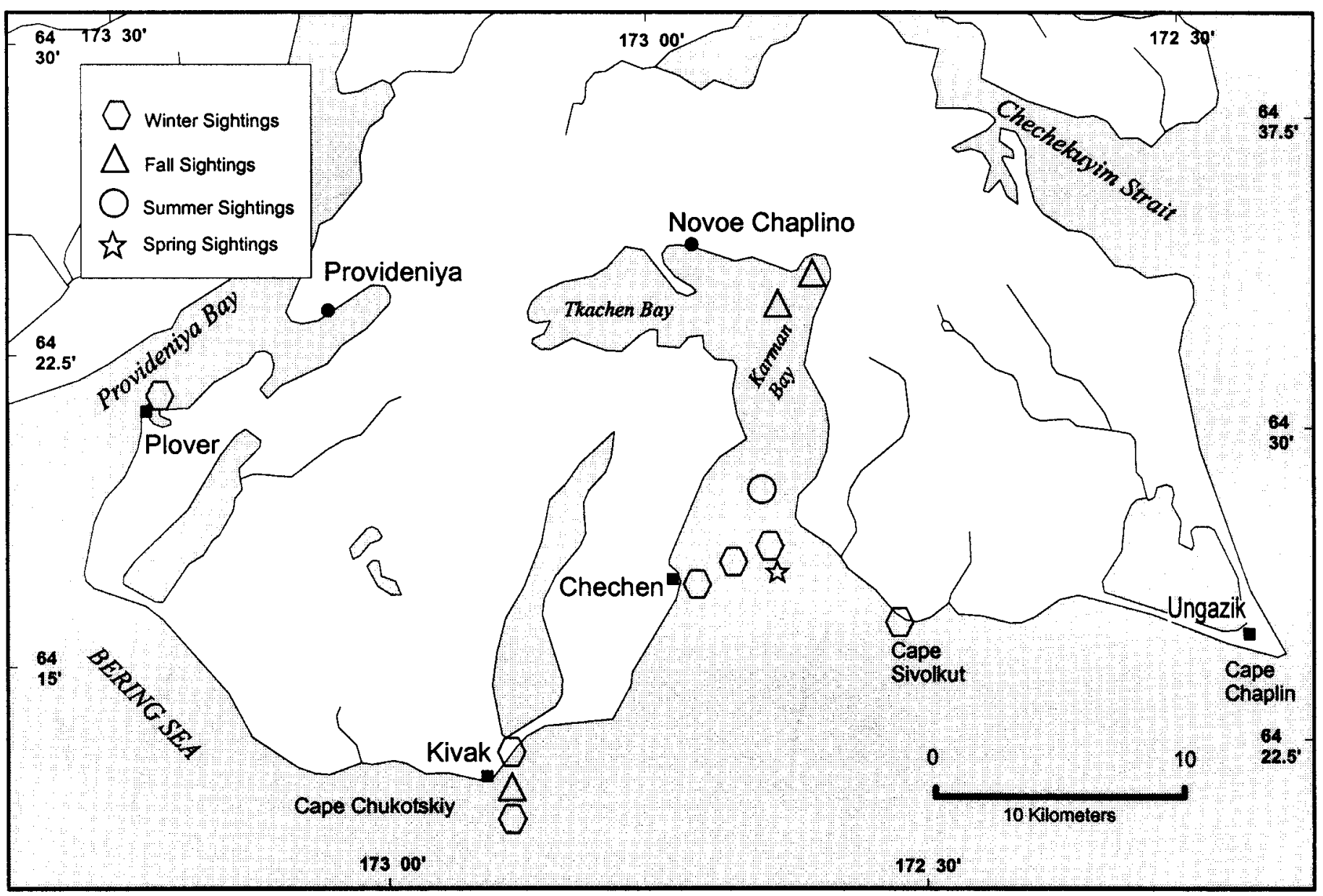

FIG. 3. Beluga sightings by season near Novoe Chaplino.

November, when bowhead whales are also migrating south and west. The beluga migration can continue into December, though at Uelen it typically ends with the formation of new sea ice in late November.

Group size varies along the coast. At Uelen (Fig. 5), belugas migrate south along the coast in small groups of five to seven. Females travel separately with their calves. Gray belugas travel in groups of two or three animals. On 24 November 1995, one Yanrakinnot hunter saw approximately 300 gray and black belugas moving as a group. They had come from southern Seniavin Strait, to Penkignei Bay, and then east into the open sea (Fig. 4). At Novoe Chaplino, the fall groups are mostly adult white belugas, but gray and black young belugas often accompany them. Fall groups of belugas can number 500 or more and typically migrate $10-15 \mathrm{~km}$ offshore. At Sireniki, the belugas are typically in larger groups than in spring, up to 15-20 animals early in the fall, with still larger and more frequent groups later. More belugas are seen in fall than in spring, including far more young.

During the fall migration, beluga movements are often associated with the distribution of fish. At Yanrakinnot in October, the belugas sometimes come into Penkignei Bay (Fig. 4), remaining there for a few days. In November 1994, there were many belugas in Chechekuyim Strait
(Fig. 3). Such concentrations are usually associated with large numbers of arctic cod. At Novoe Chaplino, the belugas follow fish, primarily arctic char (Salvelinus alpinus). When the char appear, the belugas appear also.

In winter, from January to March, belugas are seen in some years in the Sireniki area (Fig. 2), usually moving to the east. Their appearance depends on the presence of arctic cod. Belugas appear near Novoe Chaplino in winter when arctic char are present (Fig. 3). They have been observed near the entrance to Tkachen Bay, at Chechen and Cape Sivolkut, and off Kivak. In winter, small groups are composed of adult belugas, while larger groups also include young belugas. If the char travel under the shore ice, the belugas leave the area, since they cannot swim too far under the ice. The char frequently come to this area in January, and belugas are often observed at this time.

In winter, belugas occasionally appear in the Yanrakinnot area, though not every year. When they do arrive it is because there are arctic cod in the area. When the cod swim under the shore ice and beyond the reach of the belugas, the belugas leave the area again, usually heading south. These groups of belugas range from 10 to 100 animals. Where they come from at this time of year is unknown, although belugas have been seen in December near the mouth of Provideniya Bay. At Uelen, large males sometimes appear 


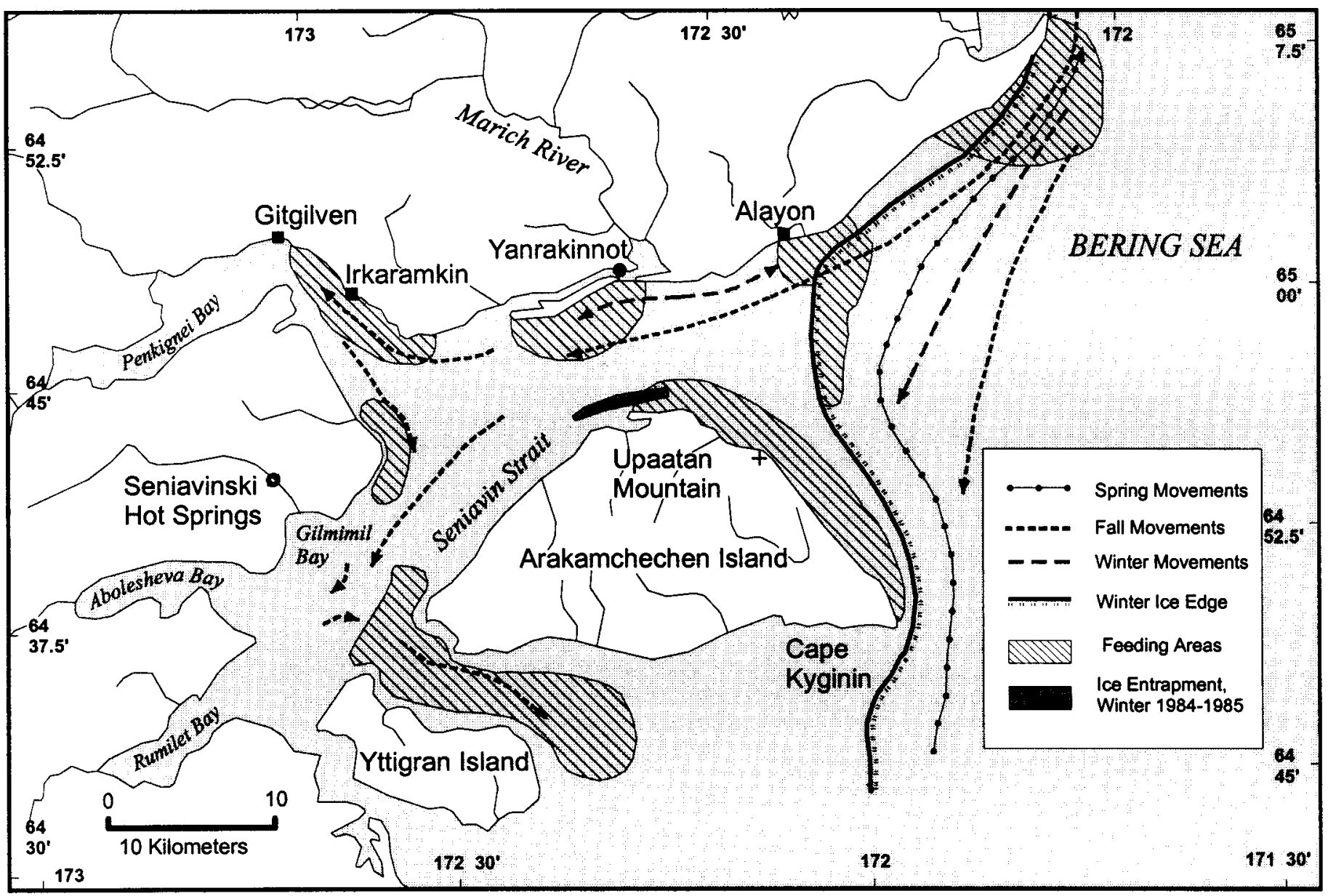

FIG. 4. Seasonal movements, feeding areas, and ice entrapment of belugas near Yanrakinnot, showing winter ice edge.

in winter, feeding on arctic char near the ice edge (Fig. 5). At times when the Bering Strait is ice-free, the belugas are seen on both the north and the south sides of the Chukotka Peninsula.

The only difference in distribution or migration noted between 20-30 years ago and today is that fewer belugas are seen today in the Sireniki area. This change may be due to increased noise in the village area, which keeps belugas further offshore and out of sight of people. Another possible cause is a decline in local fish abundance. No changes were noted in the other communities.

\section{Natural History}

Belugas eat a variety of fishes, including arctic cod, arctic char, tomcod (Elginus gracilis), herring (Clupea pallasi), capelin (Mallotus villosus), and smelt (Osmerus mordax), all of which have been found in beluga stomachs. Invertebrates are found in the stomachs of young belugas only. When the large group of belugas was trapped in the ice in Seniavin Strait in 1984-85 (Fig. 4; see below), sculpins (Cottus spp., Myoxocephalus quadricornis) were found in their stomachs.

Differences in fish distribution and abundance are the likely cause of different feeding patterns among the four study areas. In Sireniki, the most common prey species is arctic cod. Although in some cases beluga stomachs are found empty, belugas are known to come to the area when arctic cod are present. The coast near Sireniki is straight, without bays, and the strong coastal current limits the extent of shore ice, which limits the number of fish. Thus belugas do not typically stay long in the area. At Novoe Chaplino, arctic char is the only fish found in belugas' stomachs. In early March 1995, three belugas were taken, and all had arctic char in their stomachs when the hunters checked. At Uelen, as well, belugas feed mostly on arctic char. Their stomachs in spring and fall contain only arctic char.

Belugas are known to drive fish into shore, or into lagoons or river mouths. One winter in the late 1980s, some belugas arrived near Cape Yakun (Fig. 2). The belugas drove arctic cod so far in towards shore that Sireniki residents could catch the fish in their nets. In 1950, many belugas came to the Kivak area near Novoe Chaplino (Fig. 3). There were a lot of fish, and the waves from the ocean threw them onto the shore. Hunters caught arctic char with landing nets. The belugas were pushing the fish toward shore: since there was no ice, the belugas were able to come very close. Hunters were able to take 10 or 12 belugas. The belugas stayed in the area for two days. 


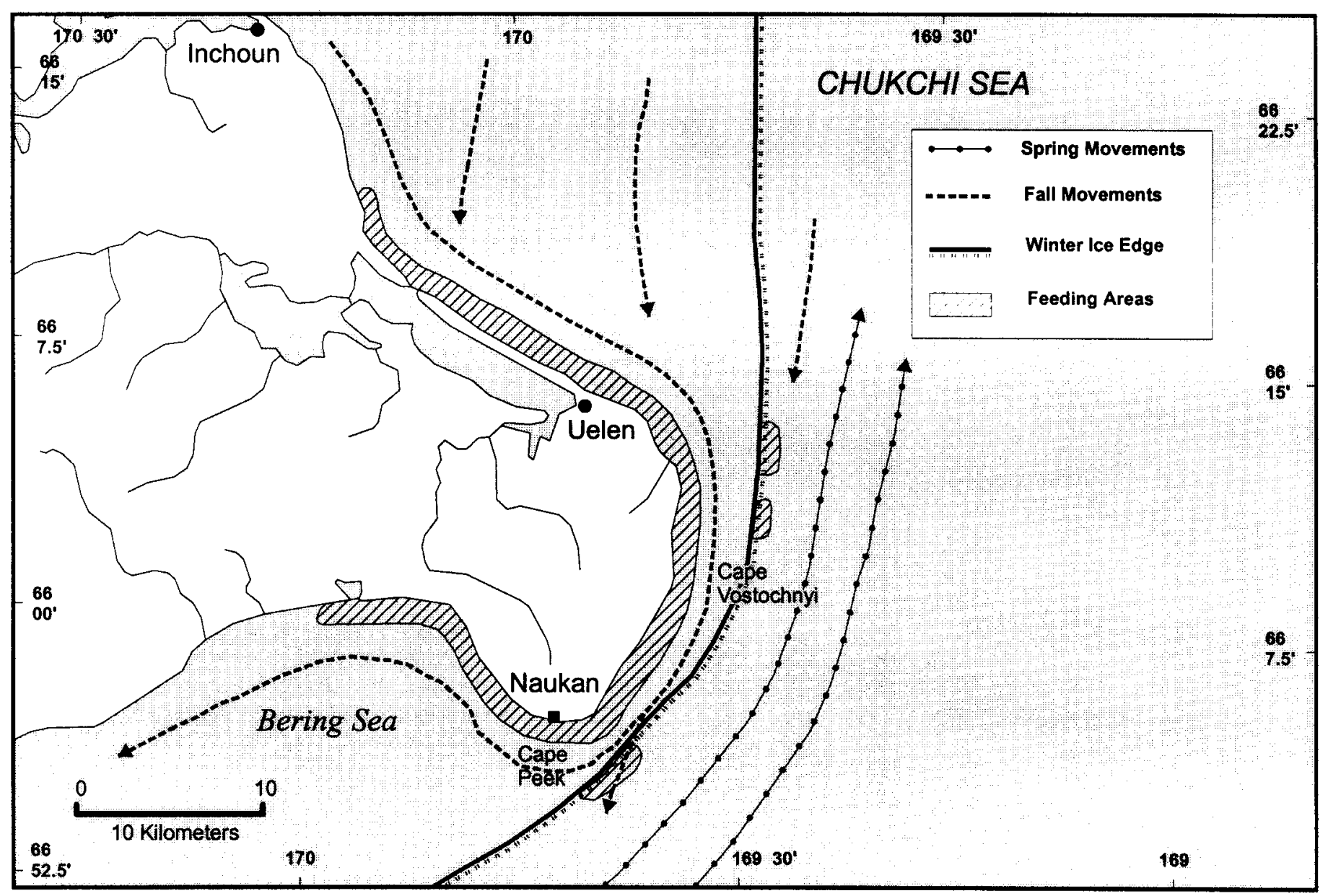

FIG. 5. Spring and fall movements and feeding areas of belugas near Uelen, showing winter ice edge.

When feeding at the ice edge, the belugas dive under the ice in groups. Typically, they stay under the ice for five to seven minutes, though they may stay under for ten minutes. During migration, typical dive times are shorter, five minutes or less. Belugas in the Yanrakinnot area feed near the ice edge in spring (Fig. 4) and in various areas in autumn and at other times of the year. The most regular area is between eastern Arakamchechen Island and Alayon, along the spring ice edge and under the ice.

While feeding, belugas emit whistles audible to people nearby. When sated, they sleep at the surface. When belugas are migrating they swim in one direction and disappear quickly, but when they are feeding, they swim and dive in different directions, though they may often return to breathe at the same place while feeding under the ice.

Belugas feed in groups, unlike seals. During feeding, they spy-hop when chasing fish. Belugas also sometimes feed in association with seals. It may be that the seals locate the fish first, since the dark seals do not scare the fish as the highly visible white belugas do. (The skin of adult belugas changes from yellow to white around June.) When belugas are feeding, other animals, including seals and birds, can often be seen in the area. Fish are often seen jumping out of the water while being chased by belugas.
Mating takes place in the fall. The male belugas whistle underwater, like bowhead whales. The females respond to the whistle, and come to mate with the males. Pregnant animals are rarely caught. One pregnant female was taken near Uelen in April, but there have been no observations of places where females give birth. Calves are black in color and feed on milk. Some harvested females have had milk. Calves keep to a position behind the mother, and they breathe, feed, and dive under ice in unison. Females with calves are usually seen in big groups of belugas. A cowcalf pair has never been seen alone. When the calves turn gray, they separate from their mothers. This usually happens when the calf is two years old.

Young belugas can stay under water for approximately as long as adults can, which can be up to 10 minutes. After surfacing, belugas breathe 7 to 12 times, and the sprays can go up to $30-50 \mathrm{~cm}$. Sleeping belugas are sometimes seen near the ice edge. Belugas sleep (or rest) on the surface, sometimes several together. One hunter saw belugas sleeping, keeping their snouts on the ice. They were not moving, and stayed there for seven or eight minutes until something scared them and they dived under the ice.

Belugas produce a variety of sounds. Whistling can signal danger; it sometimes resembles the noise a sea gull makes. Belugas also make noises while swimming through 
the ice, and often this sounds like a moaning. One hunter described it as "a kind of inside noise, as if their noses were stuffed up."

Belugas follow ice and use it as a refuge from predators. They can break sea ice up to $10-15 \mathrm{~cm}$ thick by pushing the ice up with their foreheads, creating small hummocks that look like the roof of a house. These hummocks are characteristic of belugas. When seen on a flat pan of ice, they are a sure sign that belugas have been in the area. Usually, however, the belugas use holes and other openings or swim in open water. They avoid large areas of shore ice or of pack ice under pressure.

Belugas do not always recognize the hazards associated with ice. In late November 1984, many beluga whales were discovered trapped in the ice on the south side of Seniavin Strait (Fig. 4; see also Armstrong, 1985; Ivashin and Shevlagin, 1987). Their number was estimated by some to be 3000-4000 animals. Such an event had not been seen before, nor had the hunters heard of another such entrapment in Chukotka.

Some hunters say that when a strong wind blows, the belugas come closer to shore and head for calmer areas. At Uelen, belugas gather on the south side of the peninsula when a storm comes from the north (Fig. 5). Some hunters also observe that belugas go to areas with thin ice when the wind blows. In addition, belugas are seen to swim faster and raise their heads higher out of the water when it is windy. Other hunters see no such connection, stating that windy weather does not affect beluga whales, though the whitecaps on the water make them difficult to see. If belugas are feeding, they will continue to do so in a storm, as long as the fish remain and they are near the ice edge. Beluga whales are unafraid of shallow water, and often come within $10 \mathrm{~m}$ of shore, especially when pursuing fish.

Killer whales come to the area every summer. Some participants said that killer whales have been known to swim past belugas, and that killer whales do not hunt beluga whales. Another hunter said that killer whales are the greatest enemy of beluga whales, and that all marine mammals avoid killer whales. It may be that killer whales and belugas eat the same foods, or that other factors often bring them to the same place. Belugas appear to be afraid of walrus, especially the predatory single walrus. Walrus usually do not pay attention to belugas.

Belugas are often seen with bearded and spotted seals, and they appear not to fear each other. During the ice entrapment in Seniavin Strait, the seals and belugas shared breathing holes. Belugas are seen together with bowhead whales in spring and fall and with humpback whales (Megaptera novaeangliae) in fall. Belugas appear to surface near these large whales.

Sea gulls (Larus spp.), cormorants (Phalacrocorax pelagicus), guillemots (Cepphus grylle and C. columba), and eiders (Somateria spp.) are often seen near belugas, especially when the belugas are feeding. The birds usually feed independently, but perhaps from the same stock of fish. Seabirds are unafraid of belugas, since belugas don't eat them. Sea gulls seldom spent winters in the Sireniki area in the past, but now they are common.

\section{Response to Disturbance}

Beluga whales are very sensitive to noises made by people. They are afraid of noises made on the ice by walking men, dogsleds, gunshots, and so on. When they flee noise while feeding, however, the whales return quickly, even after a shot. In the open sea, belugas flee whale boats and big ships. They can hear outboard motors from far away, and also avoid places where motors are operating on shore. When they are in large groups, they are not so wary and nervous: smaller groups frighten more easily. When belugas are feeding close to shore, they will flee if a person appears on the shore.

In some circumstances, however, belugas can become habituated to anthropogenic noise. During the ice entrapment, at first belugas fled when snow machines approached the breathing holes. After some time, however, they began to return within five minutes, and then they simply stopped reacting to the noise. This response can be regarded, however, as the behavior of weak and dying animals. In the Anadyr River, on the other hand, belugas have become used to the sounds of the port and other construction activities. While most belugas are afraid of this type of noise, the ones in the Anadyr River will swim close to the ships without fear. This fearless behavior may be due to the fact that belugas are not hunted in the Anadyr River.

\section{DISCUSSION AND CONCLUSIONS}

The information documented here extends what is found in the available literature on belugas in Chukotka (Tomilin, 1957; Kleinenberg et al., 1964; Sobolevsky and Mathisen, 1996), particularly with respect to distribution and behavior in winter. Kleinenberg et al. (1964) describe the general migratory pattern and the composition of migrating groups, as well as the association of belugas with fish and the sensitivity of local movements to tides. Their account of the prey species of belugas does not include a detailed description of the Bering and Chukchi Seas, but the species reported eaten by belugas in the Sea of Okhotsk include tomcod, arctic char, salmon, herring, and others, as well as invertebrates. Arctic cod is noted as a significant prey species in the Bering Sea. Similar results noted for the western Bering and Chukchi Seas (Seaman et al., 1982; Hazard, 1988) are also consistent with the results of this study.

Kleinenberg et al. (1964) also note that years of high continental runoff are associated with high concentrations of arctic cod near river mouths, which in turn attract high numbers of belugas. Years of low runoff, by contrast, lead to fewer fish at the river mouths and fewer belugas. Temperature and nutrients are the likely causative factors affecting the fish. 
The descriptions in this study of the size and composition of migrating groups of belugas are consistent with those of Kleinenberg et al. (1964). Males often travel separately, while mature females are most often found in mixed groups. Kleinenberg et al. report that no groups composed entirely of immature belugas are seen, while the recent account given by one hunter in Yanrakinnot of 300 immature belugas traveling together suggests that this may happen occasionally.

Other studies also note the variety of sounds made by belugas as well as their sensitivity to noise (Kleinenberg et al., 1964; Purves and Pilleri, 1983; Au, 1993; Richardson et al., 1995). They identify echolocation as a means by which belugas navigate in ice, and indicate the affinity of belugas for ice. These accounts are similar to those provided by the hunters in this study, describing a variety of sounds and the ability of belugas to identify large areas of pack ice or ice under pressure and avoid it.

The report that mating takes place in fall suggests several possible interpretations. Gestation may last a year or less, as Heide-Jørgensen and Teilmann (1994) report for belugas in West Greenland. In that case, calving would take place the following summer or fall, which is consistent with reports from other areas (Sergeant, 1973; Burns and Seaman, 1986; Heide-Jørgensen and Teilmann, 1994; Huntington et al., 1999). But gestation may last longer than a year. For belugas in Alaska, Burns and Seaman (1986) indicate a gestation period of 14.5 months and also suggest that delayed implantation may be possible. Such a gestation period would mean that fall breeding would lead to calving in late fall or early winter of the following year, a time for calving suggested by Tomilin (1957) but disputed by Kleinenberg et al. (1964). It is unknown whether delayed implantation could extend the interval between breeding and calving so that calving would occur 18 months or more after breeding (i.e., in the second spring after breeding).

The observation that fetuses are encountered infrequently may indicate sex-selective harvesting if certain migrating groups are targeted, or it may indicate nondetection of small fetuses (see discussion in Huntington et al., 1999). The observation that calves stay with their mothers for two years is consistent with estimates of lactation ranging from 12 to 32 months in other studies (Sergeant, 1973; Braham, 1984; Burns and Seaman, 1986), though different from the one-year lactation period reported by hunters in Alaska (Huntington et al., 1999).

The interactions described here of belugas with predators and potential predators are also similar to those described by Kleinenberg et al. (1964): they describe killer whales and polar bear as the main predators, but indicate that predatory single walrus are potential attackers, though their influence on the beluga population is likely small. The description herein of killer whales swimming past belugas is not found in published accounts. The observation of killer whales swimming past belugas has not been reported in previous published accounts.
The descriptions of beluga sensitivity to anthropogenic noise, which Kleinenberg et al. (1964) also report on the basis of whalers' observations, are similar to those described in Alaska (Huntington et al., 1999). When associated with hunting activity or in areas where belugas are hunted, belugas react quickly and adversely to even small noises. In areas without hunting pressure, however, belugas appear to habituate to frequent and loud noises, as in the Anadyr River (see discussion in Huntington et al., 1999; Richardson et al., 1995).

This paper is the first published work containing traditional knowledge of indigenous hunters of Chukotka. Most of the information and noteworthy observations came from older hunters who, when their hunting careers began, were little influenced by modern civilization. The interviews with these elders became most intensive when they spoke of events that happened between 1930 and 1950. (Several of the participants began hunting before the age of 10, and many of those still living continue to hunt. The information presented here thus includes current observations as well as historical ones.) While some initial group interviews were held with hunters in their thirties and forties, almost all of the information they provided was taken from books they had read. Sadly, the urgency of this research is underscored by the deaths of five of the participants during or shortly after the project period.

This situation, that the younger hunters (of belugas and other species) have little working understanding of the traditional knowledge of their elders, places serious obstacles in the path of developing traditional subsistence and perpetuating TEK in Chukotka. The education system in place for the past half-century has influenced peoples' skills, powers of observation, and other abilities. Many centuries-old traditions have also been lost. It is thus important that further efforts be made to document TEK in Chukotka both to record the knowledge that is available and to encourage greater efforts to perpetuate this knowledge and its associated practices within the communities of the region.

\section{ACKNOWLEDGEMENTS}

This research was funded by the National Science Foundation, with additional support from the U.S. Fish and Wildlife Service; the Department of Indian Affairs and Northern Development, Canada; and the Trust for Mutual Understanding. We are grateful to all for their assistance and encouragement.

The participants in the project from Sireniki were Pyotr Typykhkak, the late Nikolai Aleksandrovich Kavaugie, the late Timofei Panaugie, and the late Nikolai Nikolaevich Galgaugie. The participants in Novoe Chaplino were Vladimir Tagitutkak, the late Vladimir Nikolaevich Yatta, Vladimir Mikhailovich Nasukak, Anatoli Matveevich Ankatagin, and Pavel Ivanovich Luneut. The participants in Yanrakinnot were Konstantin Vasilievich Kimiechkin, Yevgeniy Ankalin, the late Konstantin Kovranto, and Leonid Alekseevich Kutilin. The participant in Uelen was Vasili Ivanovich Iorelo. 
Many people helped during the design and research phases of this project. To all, we give our thanks. In particular, we would like to acknowledge the great assistance that we received from each community, and from the following individuals: Lorraine Brooke, Steve Braund, Lisa Morehead, Randy Hagenstein, Sharon Rudolph, Taylor Brelsford, Fred McFarland, Chester Reimer, Caleb Pungowiyi, Bill Kemp, Kathy Frost, Lyudmila Ainana, Valentina Shevtzova, Kathy Burek Huntington, Valentina Golubeva, Yuri Bychkov, Natalia Protopopova, Ludmila Karpicheva, Sergei Rytakhrau, Natalia and Andrei Kharitonov, Oleg Veter, Igor Zagrebin, and Raisa Mymrina.

Kathy Frost, Igor Krupnik, Pierre Richard, and Thomas G. Smith provided reviews, comments, and suggestions that greatly improved the paper.

\section{REFERENCES}

ARMSTRONG, T. 1985. White whales trapped in sea ice. Polar Record 22:552.

AU, W.W.L. 1993. The sonar of dolphins. New York: Springer Verlag. 277 p.

BRAHAM, H.W. 1984. Review of reproduction in the white whale, Delphinapterus leucas, narwhal, Monodon monoceros, and Irrawaddy dolphin, Orcaella brevirostris, with comments on stock assessments. In: Perrin, W.F., Brownell, R.L., and DeMaster, D.P., eds. Reproduction in whales, dolphins, and porpoises. Report of the International Whaling Commission. Special Issue 6. 81-89.

BURNS, J.J., and SEAMAN, G.A. 1986. Investigations of belukha whales in coastal waters of western and northern Alaska. Vol. 2, Biology and ecology. Final Report. National Oceanic and Atmospheric Administration, Outer Continental Shelf Environmental Assessment Program Contract NA 81 RAC 00049. Fairbanks, Alaska: Alaska Department of Fish and Game.

HAZARD, K. 1988. Beluga whale, Delphinapterus leucas. In: Lentfer, J.W., ed. Selected marine mammals of Alaska: Species accounts with research and management recommendations. Washington, D.C.: Marine Mammal Commission. 195-235.

HEIDE-JØRGENSEN, M.P., and TEILMANN, J. 1994. Growth, reproduction, age structure and feeding habits of white whales (Delphinapterus leucas) in West Greenland waters. Meddelelser om Grønland, Bioscience 39:195-212.

HUNTINGTON, H.P. 1998a. Peoples of the Arctic: Characteristics of human populations relevant to pollution issues. In: Arctic Monitoring and Assessment Program. The AMAP assessment report: Arctic pollution issues. Oslo, Norway: Arctic Monitoring and Assessment Program. 1998b. Observations on the utility of the semi-directive interview for documenting traditional ecological knowledge. Arctic 51(3):237-242.

HUNTINGTON, H.P., and MYMRIN, N.I. 1996. Traditional ecological knowledge of beluga whales: An indigenous knowledge pilot project in the Chukchi and northern Bering Seas. Anchorage, Alaska: Inuit Circumpolar Conference. 88 p.

HUNTINGTON, H.P., and THE COMMUNITIES OF BUCKLAND, ELIM, KOYUK, SHAKTOOLIK, AND POINT LAY. 1999. Traditional knowledge of the ecology of beluga whales (Delphinapterus leucas) in the eastern Chukchi and northern Bering Seas, Alaska. Arctic 52(1):49-61.

INTERAGENCY ARCTIC RESEARCHPOLICY COMMITTEE. 1992. Principles for the conduct of research in the Arctic. Arctic Research of the United States 6:78-79.

IVASHIN, M.V., and SHEVLAGIN, K.V. 1987. The white whale (Delphinapterus leucas Pallas, 1776): Entrapment and escape in the ice of Senjavin Strait, USSR. Report of the International Whaling Commission 37:357-359.

KLEINENBERG, S.E., YABLOKOV, A.V., BELKOVICH, B.M., and TARASEVICH, M.N. [1964.] Beluga (Delphinapterus leucas): Investigation of the species. Moscow: Akademii Nauk SSSR. (Translation from original Russian by Israel Program for Scientific Translations, Jerusalem, 1969.)

KRUPNIK, I. 1994. Arctic adaptations: Native whalers and reindeer herders of northern Eurasia. Hanover, New Hampshire: University Press of New England.

PURVES, P.E., and PILLERI, G.E. 1983. Echolocation in whales and dolphins. London: Academic Press. 261 p.

RICHARDSON, W.J., GREENE, C.R., Jr., MALME, C.I., and THOMSON, D.H. 1995. Marine mammals and noise. San Diego, California: Academic Press.

SANDER, E. 1992. Whales for foxes from Arctic Circle. Inuit Tusaataat 5:9.

SEAMAN, G.A., LOWRY, L.F., and FROST, K.J. 1982. Foods of belukha whales (Delphinapterus leucas) in western Alaska. Cetology 44:1-19.

SERGEANT, D.E. 1973. Biology of white whales (Delphinapterus leucas) in western Hudson Bay. Journal of the Fisheries Research Board of Canada 30:1065-1090.

SOBOLEVSKY, Ye.I., and MATHISEN, O.A. 1996. Distribution, abundance, and trophic relationships of Bering Sea cetaceans. In: Mathisen, O.A., and Coyle, K.O., eds. Ecology of the Bering Sea: A review of Russian literature. Fairbanks, Alaska: University of Alaska, Alaska Sea Grant College Program. 265-276.

TOMILIN, A.G. [1957]. Cetacea. Vol. 9 of Heptner, V.G., ed. Mammals of the U.S.S.R. and adjacent countries. (Translation from Russian original by Israel Program for Scientific Translations, Jerusalem, 1967.) 717 p. 